\title{
THE MAPPING FULFILLMENT OF NATIONAL EDUCATION STANDARDS AND RELEVANCE TO THE LEARNING'S QUALITY AND COMPLETENESS OF LEARNING IN HIGH SCHOOL
}

\author{
Evi Elisanti ${ }^{1}$, Jauhan Budiwan ${ }^{2}$ \\ ${ }^{1}$ Universitas Duta Bangsa Surakarta, Indonesia \\ ${ }^{2}$ Institut Agama Islam Sunan Giri Ponorogo, Indonesia \\ *Corresponding Address: evielisanti@udb.ac.id
}

Naskah diterima: 2 Agustus 2021| Disetujui: 2 September 2021| Diterbitkan: 3 September 2021

\begin{abstract}
This study aims to determine the profile of the fulfillment of national education standards and the results of national exams as well as learning media and the learning process in one of the senior high schools in the city of Kediri. The method used in this research is a survey method. Data collection techniques used were observation, questionnaires, and interviews. The results showed that the profile of the fulfillment of 8 National Education Standards in one of the public high schools in Kediri City with the highest gap in the standard process component of $2.38 \%$, the standard of facilities and infrastructure of $1.43 \%$, the standard of assessment of $1.43 \%$, the standard of the content is $1.42 \%$ and the standard of education and teaching staff is $0.48 \%$. The national exam score in one of the senior high schools in Kediri has an average of 5.14. Classroom learning activities are going well but not optimal with an average value of $79 \%$. The value of fulfillment in the student's book, the value obtained is $63 \%$ and the value of deficiency is $37 \%$. The value of fulfillment in the teacher's handbook obtained a value of $75 \%$ and a deficiency value of $25 \%$.
\end{abstract}

Keywords: Profile, national education standards, learning quality, learning completeness

Abstrak: Penelitian ini bertujuan untuk mengetahui profil pemenuhan standar nasional Pendidikan, hasil ujian nasional, serta media belajar dan proses belajar pada salah satu sekolah menengah atas di kota Kediri. Metode yang digunakan dalam penelitian adalah metode survey. Teknik pengumpulan data yang diguanakan observasi, angket, dan wawancara. Hasil penelitian menunjukan bahwa profil keterpenuhan 8 standar nasional pendidikan pada salah satu SMA Negeri di Kota Kediri dengan gap tertinggi pada komponen standar proses sebesar 2,38\%, standar sarana dan prasarana sebesar $1,43 \%$, standar penilaian sebesar 1,43\%, standar isi sebesar 1,42\% seta standar pendidikan dan tenaga pendidik sebsar 0,48\%. Nilai ujian nasional pada salah satu sekolah menengah atas di Kediri memiliki rata-rata sebesar 5, 14. Kegiatan pembelajaran di kelas berjalan dengan baik tetapi belum maksimal dengan nilai rerata sebsar 79\%. Nilai keterpenuhan dalam buku siswa yang didapatkan sebesar $63 \%$ dan nilai kekurangan sebesar 37\%. Nilai keterpenuhan dalam buku pegangan guru sebesar $75 \%$ dan nilai kekurangan sebesar $25 \%$.

Kata kunci: Profil, standar nasional pendidikan, kualitas pembelajaran, ketuntasan belajar 


\section{INTRODUCTION}

Education in Indonesia in the ranking of The Program for International Student Assessment puts Indonesia at the bottom level. In 2012 Indonesia was ranked 64th out of 65 countries (Center for Educational Assessment Balitbang Kemendikbud, 2011). Indonesia's ranking from the assessment of The Program for International Student Assessment (PISA) reflects that the condition of the Indonesian education system is not yet optimal. Improving the quality of education is influenced by several factors that support learning components (Elisanti, Sajidan, \& Prayitno, 2018). Government Regulation No. 19 of 2005 stipulates 8 national education standards as minimum criteria regarding the education system in all jurisdictions of the Unitary State of the Republic of Indonesia

The government has determined the existence of national education standardization and it is not known to what extent the implementation at each level and education unit is. The implementation is arranged in stages, planned, directed, and sustainable according to local, national and global needs. The development of education in Indonesia is always improving in organizing national education in learning process activities. The purpose of educational change is to improve the quantity and quality of education and the quality of schools as formal education providers. National Education Standards become school indicators in achieving educational standards. The achievement of the Education Standards obtained by the school supports the public's trust in the school. These realities and regulations make schools try to meet the National Education Standard (Sasmito, et al., 2015). National Education Standard is serves as the basis assurance and control inplanning, implementation, and educational supervision in the context of realizing the quality of national education through evaluation, accreditation and certification.

Education is an important sector in the goals of the nation and state. Educational programs are often the flagship program of every change of government. Efforts to equalize education for all Indonesian citizens continue to be carried out. However, the task of the education sector is not only to achieve the quantity of education, but also to the quality of education provided to the nation's future successors. Therefore, in order to maintain quality education, it must be in the corridor of the standard reference set. Standards are needed so that the educational process has clear objectives. Standards created to assess education, in order to follow globalization, as well as to continuously improve quality. Thus, the standard becomes a benchmark in determining the goals of education in an effort to achieve goals.

Education in Indonesia refers to the eight educational standards initiated by the National Education Standards which consist of graduate competency standards, content standards, process standards, management standards, educators and education personnel standards, evaluation standards, 
financing standards, facilities and infrastructure standards. National Education Standards is developed and established to measure, evaluate, assess the quality of education, in order to improve the quality of education. Each component in the National Education Standards is interrelated and forms a system for providing education starting from input, process, and output. In its implementation, National Education Standards organizers often face various problems. Especially on the components of graduate competency standards that are still not in accordance with the needs of the community, business world and industry.

The second standard that still has many problems is the standard on facilities and infrastructure where not a few school buildings are also found that are not proper and lack adequate infrastructure. Another standard is the standard of educators and education personnel. The low quality of teachers and the incompatibility of the educational qualifications of educators and education personnel are problems that need to be resolved. Another issue is the issue of management standards. The low implementation of the principal's quality management system in managing the education unit and the ability of the principal in the unit to destroy the strengths and weaknesses of the education unit is not yet optimal.

The fulfillment of the National Education Standards looks at the quality of the school from the completeness of student learning seen from the passing of the results of the National Examination. All schools strive to achieve $100 \%$ graduation to improve school quality to the maximum. Evaluation of educational standards through mapping the achievement of 8 SNPs with components supporting the analysis of national exam results, media, and the learning process needs to be carried out. The results of the national exam are part of the mapping results that describe the fulfillment of the implementation of the 8 SNPs as evaluation material for better education arrangements in one of the high schools in the city of Kediri

The problem that needs to be addressed is the incompleteness of some items. It is undeniable that from year to year there are still some questions that have not shown results as expected and incomplete due to internal factors and external factors so that improvements need to be made. (Škoda, Doulík, \& Bílek, 2015; Malikah \& Widhiasti, 2019) . (Malikah \& Widhiasti, 2019; Akbar, Panuntun, $\&$ Asikin, 2021). The incompleteness of student learning due to lack of success in learning activities in the classroom is composed of several aspects ranging from learning tools. Student learning incompleteness results in students being less successful in classroom learning activities which consist of several aspects ranging from learning tools to learning evaluation and effectiveness in delivering material, and teaching materials for teacher books and student books as the main supporting 
components in influencing learning success in achieving learning mastery. students to get good and maximum learning outcomes

Based on this background, it is necessary to research by mapping the fulfillment of national education standards and their relevance to the quality of learning and mastery of high school learning.

\section{METHODS}

The research was conducted in one of the senior high schools in the Kediri district. The research focuses on the analysis of eight national education standards, national exam results, media, and the learning process in the classroom using the survey method. Data collection techniques used questionnaires, interviews, observations of schools, teachers, and all students of class XI. The data analysis technique uses a Likert scale to determine the condition of the category of compliance with national education standards. Profile of the results of the national exam by classifying the data of the UN Exhibition. Media profile and learning process using Likert and Guttman scales. The collected data is converted, so that quantitative data is obtained. The data obtained are presented in the form of tables, and diagrams showing the percentage of indicators achieved

\section{RESULTS AND DISCUSSION}

The study aims to determine the profile of meeting the needs of national education standards and the results of national exams as well as media and the learning process in one of the senior high schools in Kediri Regency, obtaining the following results:

\subsection{National Education Standard Profile}

Table 1. Comparison 8 National Education Standard at one High School in Kediri Regency

\begin{tabular}{|c|c|c|c|c|c|c|}
\hline \multirow{2}{*}{ Standard } & \multirow{2}{*}{$\begin{array}{l}\text { Number of } \\
\text { Indikator }\end{array}$} & \multirow{2}{*}{$\begin{array}{l}\text { Ideal } \\
\text { Score }\end{array}$} & \multirow{2}{*}{ Contribution (\%) } & \multicolumn{2}{|c|}{ Implementation SNP } & \multirow{2}{*}{ GAP $(\%)$} \\
\hline & & & & Score & $\%$ & \\
\hline 1. Content & 8 & 24 & 11,37 & 21 & 9,95 & 1,42 \\
\hline 2. Process & 10 & 30 & 14,22 & 25 & 11,84 & 2,38 \\
\hline 3. Graduation & 12 & 36 & 17,06 & 36 & 17,06 & 0,00 \\
\hline $\begin{array}{l}\text { 4. } \\
\text { Educators and } \\
\text { education } \\
\text { personnel }\end{array}$ & 11 & 30 & 14,22 & 29 & 13,74 & 0,48 \\
\hline $\begin{array}{l}\text { 5. Facilities and } \\
\text { infrastructure }\end{array}$ & 11 & 33 & 15,64 & 30 & 14,21 & 1,43 \\
\hline 6. Management & 4 & 12 & 5,69 & 12 & 5,69 & 0,00 \\
\hline
\end{tabular}




\begin{tabular}{|c|c|c|c|c|c|c|}
\hline 7. $\quad$ Financing & 3 & 8 & 3,79 & 8 & 3,79 & 0,00 \\
\hline 8. Assessment & 13 & 38 & 18,01 & 35 & 16,58 & 1,43 \\
\hline Total & 72 & 211 & 100 & 196 & 92,86 & 7,14 \\
\hline
\end{tabular}

Based on Table 1. Shows that the profile of the fulfillment value of the implementation of the National Education Standards is $92.86 \%$ with the details of the components as follows: the content standard component is $9.95 \%$ of the contribution fulfillment value of $11.37 \%$, the process standard component is $11.84 \%$ of the fulfillment value of the contribution is $14.22 \%$, the graduation standard component is $17.06 \%$ of the contribution fulfillment value is $17.06 \%$, the standard component of educators and education personnel is $13.74 \%$ of the contribution fulfillment value is $14.22 \%$, the standard component of facilities and infrastructure by $14.21 \%$ of the value of fulfillment of the contribution of $15.64 \%$, the management standard component of $5.69 \%$ of the value of fulfillment of the contribution of $5.69 \%$, the standard component of financing of $3.79 \%$ of the value of fulfillment of the contribution of $3.79 \%$, the standard component of the assessment is $16.58 \%$ of the contribution fulfillment value of $18.01 \%$.

\section{Profile of Absorbency of Biological Materials Based on UN Values}

Table 2. Comparison of Average National Examination Scores at School, District, Provincial and National Levels at One of Kediri City High Schools

\begin{tabular}{|l|l|l|l|l|}
\hline Tahun Ajaran & Sekolah & Kota/Kab & Propinsi & Nasional \\
\hline $2012 / 2013$ & 79,91 & 64,88 & 65,95 & 49,72 \\
\hline $2013 / 2014$ & 25,35 & 26,51 & 35,54 & 28,50 \\
\hline $2015 / 2016$ & 55,14 & 26,12 & 26,83 & 24,97 \\
\hline
\end{tabular}

Based on table 2 shows that the percentage of mastery of material absorption in one of the high schools in Kediri City with the achievement of low absorption for three consecutive years on the material of the immune system with the average score obtained at the school level, namely in $2012 / 2013$. by $79.91 \%$, in $2013 / 2014$ by $25.35 \%$, and in $2014 / 2015$ by $55.14 \%$. The material absorption capacity of this high school is below the district, provincial, and national average. 
THE MAPPING FULFILLMENT OF NATIONAL EDUCATION STANDARDS AND RELEVANCE...

Evi Elisanti, Jauhan Budiwan

\section{Profile of Classroom Learning Activities}

The profile of classroom learning activities can be seen in Table 3 as follows:

Table 3. Results of learning activities in class

\begin{tabular}{|l|l|c|}
\hline No & Components & Prosentase \\
\hline 1 & Apperception and motivation components & $90 \%$ \\
\hline 2 & Delivery of competencies and activity plans & $52 \%$ \\
\hline 3 & Implementation of learning strategies & $64 \%$ \\
\hline 4 & Application of the scientific approach & $70 \%$ \\
\hline 5 & Utilization of learning resources and media & $75 \%$ \\
\hline 6 & Implementation of learning assessment & $100 \%$ \\
\hline 7 & Involvement of students in learning & $76 \%$ \\
\hline 8 & Correct use of language and according to EYD rules & $100 \%$ \\
\hline 9 & Learning cover & $80 \%$ \\
\hline & Total & $79 \%$ \\
\hline
\end{tabular}

Based on table 3, shows that the learning activities in the classroom are going well with an average value of $79 \%$ with the details of the components as follows: the apperception and motivation components are $90 \%$, the delivery of competencies and activity plans is $52 \%$, the implementation of learning strategies is $64 \%$, the application of a scientific approach by $70 \%$, utilization of learning resources and media $75 \%$, implementation of learning assessment by $100 \%$, involvement of students in learning by $76 \%$, use of correct language and according to EYD rules by $100 \%$ and closing of learning by $80 \%$.

\section{Student Book Profile and Teacher Handbook}

The comparison profile of student books and teacher handbooks can be seen in Figure 1 as follows:

Deficiency value

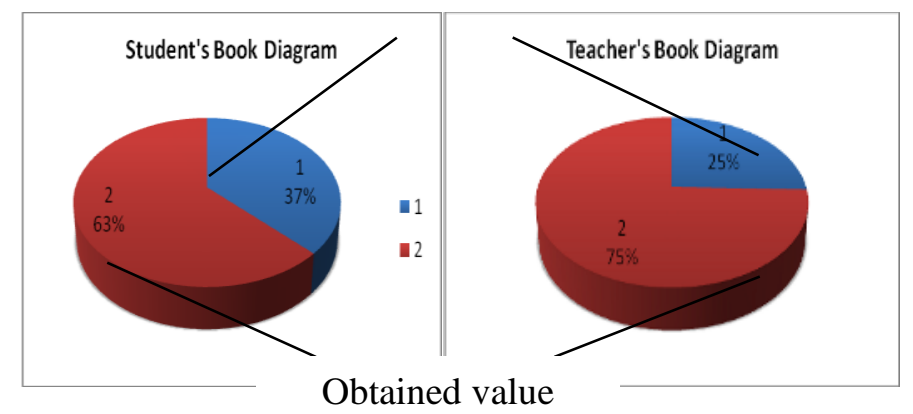

Figure 1. Comparison of the percentage of student books and teacher handbooks 
Based on Figure 1 shows that the value of fulfillment in the student's book value obtained is $63 \%$ and the value of deficiency is $37 \%$. The value of fulfillment in the teacher's handbook obtained a value of $75 \%$ and a deficiency value of $25 \%$.

The distribution of education in Indonesia has been regulated, the distribution is manifested in government regulations in the National Education Standards based on PP No.19 of 2005 as follows: 1) Content standards, 2) Process standards, 3) Graduate Competency Standards, 4) Educators and education standards, 5) Standards for facilities and infrastructure, 6) Standards for management, 7) Standards for financing, 8) Standards for assessment of education. The Ministry of Education and Culture also issues regulations and guidelines in the implementation of the eight National Education Standards so that each education unit can meet the implementation of the National Education Standards. In a quality plan, the first thing to do is quality mapping. Quality mapping is carried out through school self-evaluation (EDS) activities. All components of the education unit and stakeholders must be involved in the quality mapping process in education units such as school principals, educators and education staff, committees, parents, students and stakeholders outside the education unit. In the preparation of a quality plan that produces a school work plan (RKS) document, the institution must ensure that all of the problems in EDS to be resolved. After the preparation of the education quality improvement plan described in the planning document, the next thing to do is the implementation of the quality plan.

The implementation of the quality of education is the realization of all programs and activities that have been designed and have been described in the planning document for fulfilling the quality of education in the education unit that must be carried out by all components of education, so that educational standards can be achieved. In order for the implementation of the quality of education to run well, it is necessary to have Human Resources (HR) who have competence in the field of quality. Before implementing the quality of education, an Education Quality Assurance Team must be formed with the implementation needs, the team that has been formed must have competence regarding the quality of education. The implementation of accreditation in one of the senior high schools in Kediri is an effort to improve quality in the field of education, making schools as institutions that are required to always strive to improve the quality of education providers, so that they can produce quality graduates who are able to compete and face the demands of stakeholders. Accreditation is also carried out continuously and is held periodically as a renewal in the field of education in order to be able to face various challenges according to the times. With the holding of the accreditation program, it is expected to achieve school quality standards, institutional excellence and improve the quality of education. 
It was emphasized that the data obtained by the researcher from the results of interviews with teacher representatives that the quality mapping was formed according to the National Education Standards. For this, there is a mapping of quality standards obtained from the results of the EDS before planning the activities of the education quality assurance system. This is necessary in order to find out which standards are not working, so that improvements will be made. Quality mapping involves all school members, because we teachers are required to participate and work together to create quality education. That the quality mapping activity is part of the quality assurance system cycle that must be carried out by all components of education. In this case, quality mapping is one of the keys in the preparation of planning for improving the quality of education, the results of which will be used as a reference in setting the vision, mission and policies of schools in improving the quality of education.

Based on the results of the evaluation of the implementation of the eight national standards in one of the top high schools in Kediri district, a high gap was found in its implementation, namely the standard content of the gap value of $1.43 \%$ with indicators of the level of competency characteristics still lacking. The findings of this study show that most of the content standard indicators are met in high school in Kediri. The indicators that have been fulfilled include: have implemented KTSP in all subjects, have carried out KTSP development activities according to the provisions, have a curriculum document in the form of document I (KTSP book) ) and syllabus for all subjects, have documents for remedial and enrichment activities by teachers, have documents for Counseling and extra-curricular activities, have Competency Standards (SK) documents for all subjects, have academic calendar documents, have Minimum Completeness Criteria documents (KKM). It has also developed local content curricula that are oriented to regional needs, social needs of the community, cultural development, development of social potential with national and international competitiveness. Indicators that seem weak in their application include the development of a subject syllabus that uses 7 steps of development, the preparation of lesson plans based on the principle of encouraging active participation in learning, developing a reading and writing culture, the use of information and communication technology in learning.

The standard process value gap is $2.38 \%$ with indicators that do not meet, namely the use of less learning media, the implementation of learning does not fully refer to the lesson plans, there is no monitoring of the learning process and the delivery of the results of supervision by the principal. The research findings show that the standard process indicators are met as well as strengths, including: teachers develop the syllabus independently, teachers carry out the learning process according to the KTSP, teachers prepare lesson plans by taking into account the characteristics of students, namely: initial ability of students, intellectual level, interests and talents, motivation to learn, social skills, 
learning styles, special needs, and cultural background (multi-cultural). Likewise, the principal has carried out learning supervision which includes: planning, implementation, and assessment, the principal is following up on the results of the supervision.

The principal carries out learning supervision by paying attention to 4 stages of learning: 1) preparation, 2) implementation, 3) learning evaluation, and 4) follow-up plans. From a number of standard indicators, the process proposed is already available in schools and implemented according to standards. However, there are still some implementation indicators that need to be improved. This study found several indicators that were still weak, including; there are still many teachers who have not implemented various types of tests in evaluating learning through formative and summative assessments. In terms of the use of types of tests in assessing learning, it is very important in providing student experience to understand the application of types of tests. Likewise, the behavior of school principals' academic supervision, there are still many who have not applied academic supervision techniques simultaneously in developing the professional abilities of teachers.

The research findings show that the school principals are the most frequently used class visit academic supervision techniques, while class observation techniques, individual meeting techniques, inter-class visiting techniques, self-assessment techniques, and group supervision techniques are very rarely applied. This finding is in line with the case revealed by LPPKS, 2015). it is often found that a school principal in carrying out academic supervision only comes to school with a performance measurement instrument. Then go to class to measure the performance of the teacher who is teaching. After that, the task is completed, as if academic supervision is the same as the teacher's assessment in the implementation of learning (LPPKS, 2016). Academic supervision behavior is one example of wrong academic supervision behavior. Because academic supervision is not at all an assessment of teacher performance but rather to improve the quality of teacher competence.

The standard process components still need to be developed. Soeryanto (2013) stated that the indicators that affect the fulfillment of process standards are related to supervision, use of learning media, use of information technology in learning, and remedial teaching. low student motivation, the dominant method and model of lectures, the lack of student textbooks, and the use of learning infrastructure that is not optimal.

The standard of facilities and infrastructure has a gap of $1.43 \%$ with indicators of laboratory facilities and infrastructure not yet available, the laboratory building is still under construction. The standard of education and education personnel has a gap value of $0.48 \%$ with indicators that have not met the standard by not matching the field of work with non-linear educational backgrounds for the head of the library and laboratory staff and do not have a certificate. Indicators that affect the 
fulfillment of the standards of educators and education personnel, namely the level of teacher attendance are still below $100 \%$. This is in line with the academic qualifications of the head of the administrative staff, the suitability of the field of work with the educational background of the head of the library, and the laboratory assistant (Soeryanto, 2013).

Indicators of the standards of educators and education personnel that are met, include: a. Educators: $75 \%$ qualification of S-1/ D.IV teachers; and teachers teach according to the diploma background; and behave well. b. Education Personnel (school principal). The indicators that are met are: 1) educational qualifications are S-1/D IV; 2) have experience as an educator 3) have a certificate of educators 4 ) educators and education staff $90 \%$ are well behaved. The indicators that have not been met include: 1) the education of administrative staff is mostly not up to standard; 2) the duties of laboratory assistants and librarians are mostly carried out by subject teachers; 3) most of the counseling guidance tasks are carried out by subject teachers; 4) principal recruitment is not fully based on the principal's certificate (SKS) from LPPKS.

The standard of assessing the gap value of $1.43 \%$ is a dominant traditional assessment which should be assessment authentic in line with research conducted by Lederman et al (2013) that the assessment also comes from student work documents, learning processes, efforts, and practices in the classroom. Authentic assessment is a form of assessment in a scientific approach so that all processes carried out by students are included in the assessment. The causes of standard GAP 8 include the teacher not conveying the assessment criteria to students, in addition to showing students and the condition of existing student abilities so that it is difficult for teachers to make variations of questions according to Bloom's Taxonomy (Anwar \& Sohail, 2014; Shaarawy, 2014).

Indicators of facilities and infrastructure, including: 1) having a land area according to the provisions; 2) have their own school building; 3) has a Principal's room with a TU room; 4) have adequate learning facilities/infrastructure; 5) has a laboratory room (Science of Biology, Science of Physics, Library Room and Skills Room; 6) has room for BK, Student Council, Scouts, UKS; 7) has a teacher's room; 8) has a prayer room; 9) has facilities sports facilities (tools and fields); 10) there are warehouses and halls. Although in general, the indicators of the facilities and infrastructure mentioned above are available in all schools, but in terms of quality it seems that they are not adequate. The component of infrastructure that still not many schools have is rooms a special bath for the principal and a multipurpose room for the development of students' interests and talents, for example, the activation of various competitions such as sports, arts, drama, poetry, and other clinical services. Indicators of inadequate facilities, especially laboratory learning equipment, library equipment such as computers to store catalog data or digital libraries, sports and arts facilities and equipment. Based 
on these findings, the priority of policy fulfillment of facilities and infrastructure standards needs to be more emphasized on the completeness of learning equipment and modernization of library services through digital libraries. This is possible to encourage a culture of reading fondness by school residents, especially students.

The comparison table of the Average National Examination Scores at the School, District, Provincial, and National Levels at One High School in Kediri Regency is 5.14. Items in the low category $(<5.6)$ consist of 20 items. The lowest rank is respiration, respiratory mechanism, enzymes, antibody mechanism of action. The application of the assessment system through the national exam has an important role in evaluating the activities of the learning process and student learning outcomes. Evaluation test that aims to realize a scientific mindset in students and develop critical, creative, innovative ideas (McColskey dan O’Sullivan, 2000; Zhou, Huang, \& Tian, 2013). Assessment of student learning outcomes is based on changes in behavior made by students after experience and training in educational learning so that positive changes occur for the better for students. The need for evaluation of learning outcomes through evaluation tests on the assessment of cognitive, psychomotor, and affective aspects so that they have the potential to realize critical, creative, innovative, and scientific thinking patterns in students (Taut \& Rakoczy, 2016; Uerz, Volman, \& Kral, 2018. Soeprayitno \& Rahayu, 2019).

The analysis of learning activities in the classroom with an average value of $79 \%$ shows the process of learning activities in the classroom is going well but still not optimally. Students' learning motivation is low, dominant methods and models are less innovative, student textbooks are lacking, and the use of learning infrastructure is not optimal. Students during the learning process have not been actively involved so there is less opportunity to construct their own knowledge through experience. Students lack activity, practice, limited resources, time that limits the environment in developing exploratory thinking skills. Students memorize a lot, think a little and have little mastery of concepts other than basic knowledge so that students cannot solve problems. Students have difficulty with ideas, detecting arguments and analyzing arguments. Students lack skills, criticality and ability to present bad arguments.

The learning process is not yet a scientific approach with a student-centered orientation that is not optimal (Froyd \& Simpson, 2000). The scientific approach can be combined with an active learning model. States that active learning models include Inquiry based Learning (IBL), Problem Based Learning (PBL), Project Based Learning (PjBL), case-based, Discovery Learning, and Inquiry Learning (Smith,2007). PBL (Problem Based Learning) can improve cooperation and problems solving skills in students (Prince, 2004). Argue that students should concentrate and retain the 
information obtained during the learning process. Learning with scientific skills approach, logical thinking skills, scientific concepts and scientific attitudes has significant advantages when compared to traditional learning models (Alias \& Siraj, 2012).

Improvement of the learning approach by making preparations for learning an instructional framework and developing and applying the knowledge possessed by the teacher (Darling-hammond et al., 2020; Wiens, et al., 2020). Based on the analysis of learning planning aspects as well as assessment and learning outcomes in student books, the percentage of fulfillment is $63 \%$. As for the analysis of the teacher's handbook based on the systematic aspects of writing, material descriptions, and assessment of learning processes and outcomes, the percentage of fulfillment is $75 \%$. Efforts to improve learning in the classroom need appropriate, effective, and efficient teaching materials so that they can improve and empower student achievement, creative skills, scientific attitudes, and critical skills.

Teaching materials are all materials that are systematically arranged, which displays a complete figure of competencies that will be mastered by students and used in the learning process with the aim of planning and reviewing the implementation of learning. Teaching materials or subject matter (instructional materials) broadly consist of knowledge, skills, and attitudes that students must learn in order to achieve predetermined competency standards. Teaching materials are all forms of materials used to assist teachers or instructors in carrying out learning activities. In the field application of teaching materials in schools, teacher assistance and modifications are needed in their use so that these sources of teaching materials can be utilized by students.

Teachers design and make teaching materials according to the needs of their students, teachers should also be able to provide an assessment either directly or indirectly on the entire learning process, this is intended to assess the extent to which students have mastered the subject matter and evaluate the teaching materials that the teacher uses are appropriate. help students in learning or make it difficult for students to learn. This needs to be known because if the teacher has wrongly designed the lesson, it will have an impact on student learning outcomes. Based on several theories related to the development of teaching materials and observations, the learning process experienced by students will be easier to understand and meaningful when teachers are able to develop their own teaching materials and then use them in the learning process with students. This shows that teachers are creative and understand what students need if a teacher is able to understand what students need to learn and how teachers can help students achieve learning outcomes that have been set before the learning process takes place. So that in the learning process the development of teaching materials is 
a very important thing that teachers need to do to facilitate and improve understanding related to the field of science that students are studying.

Teaching materials that have the potential to empower higher-order thinking skills are modules. The module has the characteristics of self-instructional, self-contained, stand-alone, adaptive, and user friendly (Sukiman, 2012; Wong, Chen, \& Osman, 2017)). Model-based modules are one of the alternative teaching materials to empower students' thinking skills, students' scientific attitudes and are effective in improving students' cognitive learning outcomes. Turiman, Omar, Osman, and Daud state that students must have skills in the 21 st century to be able to emerge and hone various kinds of skills and student independence.

The advantages of using the learning module for students include: 1) providing feedback after students have finished using the module because the module is equipped with a material mastery level formula to determine the level of student learning outcomes so that students can immediately correct their learning deficiencies, 2) provide opportunities for students to master the subject matter in a comprehensive manner. complete, 3) make it easier for students to achieve learning goals because the preparation is specifically designed for certain purposes, 4) provide motivation to students because it contains activities because it contains activities and regular learning steps, 5) is flexible so that it can be used by students with various student backgrounds and 6) opens up opportunities for collaboration among students

\section{CONCLUSION}

Compliance Profile 8 National Education Standards at one of the public high schools in Kediri Regency with the highest gap in the standard process component of $2.38 \%$, the standard of facilities and infrastructure of $1.43 \%$, assessment standard of $1.43 \%$, the content standard of $1,42 \%$ and the standard of education and teaching staff is $0.48 \%$. The national exam score in one of the senior high schools in Kediri has an average of 5.14. Classroom learning activities are going well but not optimal with an average value of $79 \%$. The value of fulfillment in the student's book the value obtained is $63 \%$ and the value of deficiency is $37 \%$. The value of fulfillment in the teacher's handbook obtained a value of $75 \%$ and a deficiency value of $25 \%$.

Research on the profile of national education standards, results of national exams, media, and the learning process can be used as a reference for making improvements to education and learning in the city of Kediri through research that will be developed. Improving the quality of education needs to be done with educational research that can evaluate the learning components. 
THE MAPPING FULFILLMENT OF NATIONAL EDUCATION STANDARDS AND RELEVANCE...

Evi Elisanti, Jauhan Budiwan

\section{ACKNOWLEDGEMENT}

Researchers would like to thank all those who have helped in this research.

\section{REFERENCES}

Akbar, S., Panuntun, A., \& Asikin, M. (2021). Kemapuan Berpikir Kreatif Ditinjau Dari Self Regulated Learning dengan Pendekatan Open-Ended Pada Model Pembelajaran Creative Problem Solving. QALAMUNA: Jurnal Pendidikan, Sosial, Dan Agama, 13(1), 11-22. https://doi.org/10.37680/qalamuna.v13i1.847

Alias, S \& Siraj, S. (2012). Design And Development Of Physics Module Based On Learning Style And Appropriate Technology By Employing Isman Instructional Design Model. Journal of Educational Technology. 11 (4): 84-93

Anwar, H. N., \& Sohail, M. M. (2014). Assessing the Learning Level of Students through Bloom 's Taxonomy in Higher Education in Punjab. Journal of Educational and Social Research, 4(3), 83-88. https://doi.org/10.5901/jesr.2014.v4n3p83

Darling-hammond, L., Flook, L., Cook-harvey, C., Barron, B., Flook, L., Cook-harvey, C., ... Barron, B. (2020). Implications for educational practice of the science of learning and development. Applied Developmental Science, 24(2), 97-140. https://doi.org/10.1080/10888691.2018.1537791

Elisanti, E., Sajidan, S., \& Prayitno, B. A. (2018). The Effectiveness Of Inquiry Lesson-Based Immunity System Module To Empower The Students'critical Thinking Skill. Edusains, 10(1), 97-112. http://dx.doi.org/10.15408/es.v10i1.7259

Froyd, J., \& Simpson, N. (2000). Student-Centered Learning Addressing Faculty Questions about Student- centered Learning. What is meant by Student-centered Learning ( SCL ).

Malikah, N., \& Widhiasti, L. D. (2019). Penerapan Metode Kartu Make And Match terhadap Hasil Belajar Matematika pada Materi Bangun Ruang. QALAMUNA: Jurnal Pendidikan, Sosial, Dan Agama, 11(2), 45-59. https://doi.org/10.5281/zenodo.3559279

McColskey, Wendy \& O'Sullivan,Rita. 2000. How to Assess Student Performance in Science: Going Beyond Multiple-Choice Tests. North Carolina: University Of North Carolina

Prince, M. (2004). Does Active Learnin g Work? A Review of the Research. Journal of Engineering Education. 93(3): 223-231. https://doi.org/10.1002/j.2168-9830.2004.tb00809.x 
Sasmito, A., Elisanti, E., Susilowati, S., Yuliati, Y., \& Sajidan, S. (2015). Profil Ketuntasan Belajar Biologi SMA Negeri di Kabupaten Magetan, Relevansinya dengan Profil Pemenuhan Standar Nasional Pendidikan dan Kegiatan Pembelajaran. In Prosiding SNPS (Seminar Nasional Pendidikan Sains) (Vol. 2, pp. 632-640).

Shaarawy, H. Y. (2014). The Effect of Journal Writing on Students' Cognitive Critical Thinking Skills A Quasi-Experimental Research on an English as a Foreign Language ( EFL ) Undergraduate Classroom in Egypt, 3(4), 120-128. https://doi.org/10.5430/ijhe.v3n4p120

Škoda, J., Doulík, P., \& Bílek, M. (2016). Learning Style As A Factor Influencing The Inquiry-Based Science Education At Lower. Journal of Baltic Science Education, 15(5), 588-601.

Smith, R.S. (2007). Experiencing the Process of Knowledge Creation: the Nature and Use of InquiryBased Learning in Higher Education. Journal of Higher Education. 2(183).

Soeprayitno, \& Rahayu, P. Y. (2019). The Influence of Knowledge Management Towards Motivation Teaching in Boarding Schools. International Journal of Active Learning, 4(2), 114-125. https://doi.org/10.15294/ijal.v4i2.18109

Sukiman (2012). Pengembangan Media Pembelajaran. Yogjakarta: Pedajogja

Turiman, P, Omar, J, Daud, A. M, Osman, K. (2012). Fostering the 21th Century Skills through Scientific Literacy and Science Process Skills. Procedia - Social and Behavioral Sciences 59, 110-116. https://doi: 10.1016/j.sbspro.2012.09.253

Taut, S., \& Rakoczy, K. (2016). Observing instructional quality in the context of school evaluation. Learning and Instruction, 46, 45-60. https://doi.org/10.1016/j.learninstruc.2016.08.003

Uerz, D., Volman, M., \& Kral, M. (2018). Teacher educators' competences in fostering student teachers' proficiency in teaching and learning with technology: An overview of relevant research literature. Teaching and Teacher Education, 70, 12-23. https://doi.org/10.1016/j.tate.2017.11.005

Wiens, P. D., Locasale-crouch, J., Cash, A. H., \& Escudero, F. R. (2020). Preservice Teachers' Skills to Identify Effective Teaching Interactions: Does It Relate to Their Ability to Implement Them ? Journal of Teacher Education 1, 1-15. https://doi.org/10.1177/0022487120910692

Wong, C., Chen, C., \& Osman, K. (2017). Cultivating Marginalized Children 's Scientific Literacy in Facing the Challenges of the 21st Century, 3(1), 167-177. https://doi.org/10.14456/K12STEMED.2017.3 
THE MAPPING FULFLLMENT OF NATIONAL EDUCATION STANDARDS AND RELEVANCE...

Evi Elisanti, Jauhan Budiwan

Zhou, Q., Huang, Q., \& Tian, H. (2013). Developing Students ' Critical Thinking Skills by TaskBased Learning in Chemistry Experiment Teaching, Journal Creative Education, 4(12), 40-45. http://dx.doi.org/10.4236/ce.2013.412A1006 